\title{
ПРИМЕНЕНИЕ ТРАНСФОРМАЦИОННОЙ ИГРЫ ДЛЯ САМОПРОФИЛАКТИКИ СИНДРОМА ЭМОЦИОНАЛЬНОГО ВЫГОРАНИЯ У ВОСПИТАТЕЛЕЙ ДЕТСКИХ ОБРАЗОВАТЕЛЬНЫХ УЧРЕЖДЕНИЙ
}

\author{
М. Л. Новикова \\ Московский гуманитарный университет
}

\begin{abstract}
Аннотация: В статье проведен теоретический обзор исследований, посвященных проблеме идеопатического бесплодия, как одного из факторов эмоционального выгорания воспитателей детского дошкольного учреждения. Выдвинута гипотеза применения трансформационной игры, как одного из методов диагностического и профилактического инструмента.

Ключевые слова: эмоциональное выгорание; стресс; профилактика; синдром эмоционального выгорания; профилактика синдрома эмоционального выгорания; идеопатическое бесплодие; трансформационная игра; психологическое бесплодие
\end{abstract}

\section{TRANSFORMATIONAL GAME FOR THE PREVENTION OF BURNOUT SYNDROME AMONG TEACHERS AT CHILDREN'S EDUCATIONAL INSTITUTIONS}

\author{
M. L. Novikova \\ Moscow University for the Humanities
}

\begin{abstract}
The article provides a theoretical review of studies into the issue of ideopathic infertility as one of the factors of emotional burnout among kindergarten teachers. A hypothesis is put forward for the use of a transformational game as one of the methods of the diagnostic and preventive tool.

Keywords: emotional burnout; stress; prevention; burnout syndrome; prevention of burnout syndrome; ideopathic infertility; transformational game; psychological infertility
\end{abstract}

С 2000-х гг. в России произошел всплеск интереса к трансформационным играм и психологи стали использовать их как один из инструментов диагностики.

По прогнозам отечественных психологов, направление игровой психотерапии в скором времени займет полноправное место наряду с традиционными направлениями психологической помощи. Еще 10 лет назад мы говорили о применении игровой терапии только к детскому возрасту, сегодня 
же в трансформационные игры играют и взрослые. Данное направление с каждым годом становится все более популярным, как тут не вспомнить слова знаменитого ученого В. Франкла, который в своей книге «Человек в поисках смысла» писал: «У каждого времени свои неврозы - и каждому времени требуется своя психотерапия» (Франкл, 1990: 24). Нельзя отрицать, что интерес к игре заложен в нас с детства, именно в игре мы чувствуем подлинные эмоции и неосознанно открываемся чувствам. Тогда, действительно, почему бы не использовать игру как инструмент и, по сути, использовать метод организации терапевтического процесса в форме игры? (Греков, 2016).

В процессе первичных исследований в рамках написания диссертации по профилактике синдрома эмоционального выгорания воспитателей доУ, при проведении устной беседы было отмечено, что одним из факторов синдрома является отсутствие собственного ребенка по причине идеопатического бесплодия.

Одним из основных факторов бесплодия психологи выделяют влияние стресса.

Часто существует ситуация, когда человек не может осознать причину стресса, т. к. она находиться у него глубоко в подсознании. Также, отрицательными факторами отсутствия желаемой беременности признаются:

- психологическая травма,

- отклонение в психоэмоциональной сфере,

• внутренние конфликты,

- страхи.

Если женщина внутренне не чувствует, что может защитить своего ребенка, беременность не наступает. Но, как только женщина понимает и осознает причины вызвавшие негативное психоэмоциональное состояние, как только она признает свою «взрослость», прорабатывает негативные установки, она осознает, что способна защитить своего ребенка и жить ради него - ситуация меняется в положительную сторону и часто врачи называют это чудом (Мясогутова, 2018).

В части воспитателей ДОУ само по себе осознание собственной бездетности и при этом постоянное присутствие рядом с несовершеннолетними воспитанниками, вызывает чувство социальной неполноценности и является сильным стрессом. Поэтому данная категория исследуемых в силу сложившихся профессиональных обстоятельств наиболее часто переживает отрицательные эмоции, что негативно сказывается в итоге на психоэмоциональное состояние в целом.

Выявление же подобных проблем (по идеопатическому бесплодию) у женщин любых профессий осложняется тем, что в первичной клинической 
беседе не всегда можно выявить, во-первых, сам факт наличия бесплодия, как такового, так как женщины стесняются говорить об этой проблеме, во-вторых, страхи и негативные установки сопутствующие ему. Психолог вынужден проводить несколько сессий для того, чтобы не только выявить, но и понять причину их возникновения.

Учитывая новые тенденции и опыт психологической работы в качестве пренатального психолога и игропрактика мною была разработана трансформационная игра «Хочу стать счастливой мамой», алгоритм которой включает в себя выход на позитивные установки, используемые в последствии в комплексной аутосуггестии.

В игре предусмотрен алгоритм выявления страхов, негативных (вытесненных) установок. Кроме того, на каждый выявленный отрицательный элемент с помощью метафорических ассоциативных карт, сама пациентка выбирает наиболее ресурсный для себя путь преодоления конкретной негативной ситуации. В данном случае психолог является лишь инструментом, помогающим ей принять экологичное решение.

В процессе игры под руководством опытного психолога возможно обойти осознанные и неосознанные формы защиты, выявить факторы стресса, сформировать позитивный настрой и мотивировать исследуемых выполнять методику по аутогенной тренировке с соответствующими позитивными установками (аффирмациями) самостоятельно.

Так же, учитывая опыт психоаналитиков, которые полагают, что стыд и чувство вины всегда сопутствуют женщине в ситуации, когда она не смогла забеременеть, как все остальные, выносить и родить ребенка и тем самым продолжив свой род, в игре предусматривается «благословение рода», которое несет в себе положительные послания и снижает тревожность женщины (Мясогутова, 2018).

В процессе игры, в силу складывающихся обстоятельств, предлагаемых игрой, пренатальным психологом оказывается психологическая помощь в рамках групповой терапии и проводится разъяснительная работа по процессам репродуктивной функции и психологии материнства.

Одним из методов для проработки выявленных причин выбрана аутосуггестивная терапия, неоднократно подтвердившая свою эффективность. Но до сих пор, в силу существующих шаблонов отношение к этому методу у пациенток неоднозначное.

При этом отмечено, что если исследуемым давать рекомендацию по использованию установок напрямую, то срабатывает элемент отрицания и отстранения от подобных рекомендаций. Если рекомендации получены в процессе проведения игры, то исследуемые более восприимчивы, что резко повышает позитивный исход последующей терапии. 
Кроме того в структуре игры предусмотрен элемент групповой терапии, при обсуждении страхов и негативных установок, что так же положительно влияет на результат.

На сегодняшний день в эксперименте приняло участие 20 человек воспитатели детских садов (г. Москвы и Московской области), женщины от 25 до 35 лет в г. Москве. У всех отмечено улучшение общего позитивного настроя и повышение уровня мотивации к своей деятельности, что является важным условием, учитывая социальную значимость профессии воспитателя.

Учитывая в целом позитивное отношение исследуемых к игровому процессу и положительную динамику изменений психологического состояния, считаю целесообразным в дальнейшем продолжать исследования и рассматривать использование трансформационных игр в качестве диагностического и терапевтического инструмента игры, или как элемент дополнительной диагностики при проведения терапии.

Кроме того, учитывая вышесказанное, считаю, что трансформационные игры должны создаваться профессиональными психологами, которые учитывают различные особенности психики человека.

\section{СПИСОК ЛИТЕРАТУРЫ}

Греков, И. В. (2016) Игровая терапия взрослых: современные терапевтические трансформационные технологии Московский институт психоанализа. // Человек. Искусство. Вселенная. № 1. С. 379-386.

Масягутова, Л. Ф. (2018). Психологический взгляд на причины идеопатического бесплодия // Вестник науки и образования. № 17-1 (53). С. 113-116.

Франкл, В. (2012) Человек в поисках смысла. М.: Прогресс. 366 с.

Дата поступления: 21.12.2019 2.

Новикова Марина Львовна - аспирант кафедры психологии и истории психологии Московского гуманитарного университета Адрес: 111395, Россия, г. Москва, ул. Юности, д. 5. Тел.: +7 (499) 374-70-20. Эл. адрес: mnovikova01@yandex.ru. Научный руководитель - д. м. н., профессор В. М. Звоников.

Novikova Marina Lvovna, Postgraduate Student, Department of Psychology and History of Psychology, Moscow University for the Humanities. Postal address: 5, Yunosti St., Moscow, Russian Federation, 111395. Tel.: +7 (499) 374-70-20. E-mail: mnovikova01@yandex.ru. Scientific Advisor - V. M. Zvonikov, Doctor of Medicine, Professor. 


\section{Для цитирования:}

Новикова М. Л. Применение трансформационной игры для самопрофилактики синдрома эмоционального выгорания у воспитателей детских образовательных учреждений [Электронный ресурс] // Научные труды Московского гуманитарного университета. 2020. №1. URL: http://journals.mosgu.ru/trudy/article/view/1120 (дата обращения: дд.мм.гг.). DOI: 10.17805/trudy.2020.1.1 